УДК 94 (477-22) «1917»396.9

DOI: https://doi.org/10.33782/eminak2020.3(31).439

\title{
УКРАЇНСЬКЕ СУСПІЛЬСТВО НА ПОЧАТКОВОМУ ЕТАПІ УКРАЇНСЬКОЇ РЕВОЛЮЦІЇ (БЕРЕЗЕНЬ - ЛИСТОПАД 1917 Р.): ДО ПИТАННЯ ПОЛІТИЧНОЇ ЕМАНСИПАЦІЇ ЖІНОК В УКРАЇНІ
}

\author{
Валерія Мотуз \\ Черкаський національний університет імені Богдана Хмельницького (Черкаси, Україна) \\ e-mail: v.k.motuz@ukr.net \\ ORCID: https://orcid.org/0000-0002-9974-7205
}

Стаття присвячена проблемі активізації політичної свідомості жіноцтва у Наддніпрянщині (Україні). На сьогодні вона є малодослідженою, однак важливою складовою декількох пов'язаних між собою тем, таких як: «жіноче питання» в Україні у ХХ ст., український жіночий рух у ХХ ст., украӥнський національний рух у ХХ ст., Українська революція 1917-1921 рр., а також політизація жіноцтва в Україні. Специфіка та значення даного процесу, що мав місце в житті українського суспільства у першій чверті XX ст., не втратили своєї актуальності й нині, тому його вивчення та популяризація може позитивно вплинути як на розвиток українського жіночого руху, так і на досягнення фактичного гендерного паритету у сфері публічної влади в Україні. Тож, враховуючи викладене вище, досліджений аспект теми має не лише наукове, суспільно-політичне, але й практичне значення.

Ключові слова: украӥнське жіноцтво, жіночий рух, політична емансипація жінок, політична свідомість жінок

Постановка проблеми. Історія засвідчує, що українській ментальності притаманна толерантність і повага до соціальної, зокрема політичної активності жінки ${ }^{1}$. Тож, коли представниці громадських товариств і політичних об'єднань Наддніпрянщини (України)2, зокрема жіночих організацій, долучились до розбудови української державності одразу ж, щойно розпочалась Українська революція 19171921 рр., - це виявилось гармонійним влиттям жінок у середовище державних реформаторів, досить спокійно сприйнятим українським суспільством у Наддніпрянщині ${ }^{3}$.

3 самого початку Української революції 1917-1921 рр. на території Україні діяли жіночі громадсько-політичні об'єднання трьох типів: ліберально-демократичні, націонал-патріотичні та соціал-демократичні4,5. Лідируючі позиції у плані соціальної активності в національно-демократичних перетвореннях в Україні з березня до листопада 1917 р. займали представниці ліберально-демократичної та націо-

\footnotetext{
${ }^{1}$ Морщакова 0. Історико-соціальні та правові аспекти гендерної рівності. URL: http://divovo.in.ua/download/morshakova-o-s-istoriko-socialeni-ta-pravovi-aspekti-gendernoy.doc

2 Україна - офіційна назва історико-географічного краю, яку використовувало з березня до листопада 1917 р. керівництво Української Центральної Ради (УЦР).

3 Петришина Л. Гендерні особливості українського національного руху XIX - початку XX ст. // Науковий вісник міжнародного гуманітарного університету. 2016. № 2-2211. С. 18.

4 Тимченко Ж. Участь жінок-робітниць Києва у революційній боротьбі (березень 1917 - січень 1918 р.) // Український історичний журнал. 1982. Ч. 1. С. 59.
} 
нал-патріотичної течій українського жіночого руху5.

Їхні ідеологічні засади в окреслений період не мала суттєвих відмінностей від попереднього історичного етапу їхнього розвитку. Так, представниці ліберальнодемократичної та націонал-патріотичної течій українського жіночого руху в перший і другий етапи доби УЦР продовжили пропагувати ідею гендерної рівності у суспільстві та демонстрували свою готовність відроджувати українську державність пліч-о-пліч з чоловіками ${ }^{6}$.

Що не скажеш про саму специфіку їх функціонування у досліджуваний період. Остання зазнає кардинальних змін завдяки поваленню російського самодержавства та приходу до влади в Росії ліберально-демократичних сил7. Зокрема, в нових суспільно-політичних умовах представниці ліберально-демократичної та націонал-патріотичної течій українського жіночого руху в Україні перешли від суто громадсько-політичної діяльності, плекаючи надії та сподівання щодо відродження української державності, до конкретних дій - її розбудови, опинившись поміж національної державно-політичної елітив.

Наукова новизна. У цій статті вперше у сучасній українській історіографії комплексно досліджено проблему долучення соціально активного жіноцтва Наддніпрянщини, у тому числі представниць ліберально-демократичної та націоналпатріотичної течій українського жіночого руху краю до участі в національнодемократичних перетвореннях початкового етапу Української революції 19171921 рр. Висвітлено її з позиції переходу українського суспільства в березні 1917 р. на якісно новий рівень гендерних відносин у публічній сфері його життя, що, зі свого боку, створювало широкі можливості для політичної емансипації жінок в Україні.

Було визначено умови й обставини, в яких перебувало українське суспільство 3 березня до листопада 1917 р., що сприяли не лише розширенню можливостей самореалізації жінок України у громадсько-політичному житті краю, але й стали чинником активізації політичної свідомості жіноцтва та стимулювання їхньої громадської активності. Насамперед, йдеться про здійснення революційних нововведень українською національною політичною елітою у напрямку створення політико-практичних засад гендерної рівності в українському суспільстві, зокрема перетворення жінок в Україні з об'єкта у суб'єкт політичної діяльності, не чекаючи зрушень у гендерній політиці Тимчасового уряду, тобто зміни нормативноправової бази колишньої Російської імперії з явною антифеміністичною установкою.

Розкрито організаційно-правові основи участі жінок у роботі державнополітичних структур та інститутах громадянського суспільства України у вище-

\footnotetext{
5 Олійник Н. Громадсько-політична активність українських жінок (1917-1939рр.). Київ, 2013. C. $174,176$.

6 Оніщенко О. Жінки в Українській Центральній Раді // Література та культура Полісся. Серія: Історичні науки. 2016. Вип. 85. С. 84.

7 Оніщенко О. Трансформація гендерних стереотипів у контексті революційних подій 1917 року // Наукові записки Національного університету «Острозька академія». Серія: Гендерні дослідження. 2015. Вип. 1. С. 159; Оніщенко О. Жінки в суспільно-політичному житті України. 1917 рік: Автореф. дис... канд. іст. наук. Київ, 2008. С. 11.

8 Оніщенко О. Жінки в Українській Центральній Раді... С. 86; Мужук М. Суспільно-правовий статус та громадсько-політична діяльність жінок Чернігівщини у період національно-культурного відродження XIX - початку XX ст. URL: http://eprints.kname.edu.ua/44337/
} 
вказаний період. Звернуто увагу на місце соціально активного жіноцтва в цих інституціях, а також дана оцінка ефективності їхньої діяльності.

Аналіз останніх досліджень і публікацій. Історіографічний огляд проблеми політичної емансипації жінок в Україні на початковому етапі Української революції 1917-1921 рр., а саме від березня до листопада 1917 р., свідчить про відсутність комплексних наукових досліджень, присвячених цій темі. Однак відповідна проблематика знайшла своє відображення в історичній науці.

Так, процес історіографічного осмислення відповідного процесу, що мав місце в житті українського суспільства у вище окреслений період розпочався у тому ж столітті. Насамперед, йдеться про наукові доробки істориків української діаспори, в яких прослідковується наступна тенденція - дослідження ролі жінки в українському суспільстві періоду Української революції 1917-1921 рр. крізь призму державного підходу. I хоча їхнім роботам все ж притаманний певний публіцистичний виклад, проте вивчення ними жіночого аспекту українського національновизвольного руху, зокрема доби УЦР, було одним із перших, що поповнило історіографічну базу досліджуваної проблеми. У цьому плані досить плідним виявилося дослідження американського історика українського походження М. БагачевськоїХом'як9, в якій авторка приділяє увагу діяльності українського жіночого руху, у тому числі на початковому етапі Української революції 1917-1921 рр. Так, з одного боку, вона зазначає про його діяльність як про цілком самостійне явище, а з іншого, - вказує на існування тісного взаємозв'язку між ним та українським національно-визвольним рухом.

Серед праць сучасного періоду виділяються дослідження К. Кобченко10, 0. Кочерги11, О. Лабур ${ }^{12}$, Д. Міщенко ${ }^{13}$, О. Морщакової14, I. Мудрої та М. Куцої15, М. Мужук ${ }^{16}$, П. Нестерцової-Собакарь ${ }^{17}$ ․ Олійник ${ }^{18}, \quad$ О. Оніщенко ${ }^{19}$,

\footnotetext{
${ }^{9}$ Богачевська-Хомяк М. Білим по білому: Жінки в громадському житті України, 1884-1939. Київ, 1995. $424 \mathrm{c}$.

10 Кобченко К. Гендерні зміни в українському суспільстві в сер. XIX - на поч. XX ст. як складова європейських цивілізаційних процесів // Українознавчий альманах. 2012. № 8. С. 271-274.

11 Кочерга 0. Софія Русова про роль жінки у суспільному розвитку. URL: https://eprints.oa.edu.ua/5362/1/6.pdf

12 Лабур 0. «Вікно можливостей?»: гендерна ситуація на хвилі революційної політики з лютого 1917 р. в Україні // Сторінки історії: збірник наукових праць. 2019. № 49. С. $42-58$.

13 Міщенко Д. Політизація українського жіночого руху наприкінці XIX - на початку XX ст. // Збірник наукових праць студентів, аспірантів і молодих вчених «Молода наука - 2011»: у 5 т. / Запорізький національний університет. Запоріжжя: Просвіта, 2011. Т. 5. С. 113-115.

14 Морщакова О. Вказ. пр.

15 Мудра І., Куца М. Еволюція українських жіночих журналів // Соціальні комунікації. 2018. № 6 (58). С. 45-49.

16 Мужук М. Вказ. пр.

17 Нестерцова-Собакарь О. Правове становище жінки на українських землях у складі Російської імперії у другій половині XIX - на початку XX ст.: монографія. Дніпро: Дніпропетровський державний університет внутрішніх справ, 2016.

18 Олійник Н. Громадсько-політична активність українських жінок...; Олійник Н.Ю. Особливості залученості жінок у громадсько-політичні процеси (середина XIX ст. - початок XX ст.) // Гілея: науковий вісник. 2013. № 72. С. 75-80.

19 Оніщенко О. Жінки в Українській Центральній Раді // Література та культура Полісся. Серія: Історичні науки. 2016. Вип. 85. С. 81-90; Оніщенко О. Трансформація гендерних стереотипів у контексті революційних подій 1917 року // Наукові записки Національного університету «Острозька академія». Серія: Гендерні дослідження. 2015. Вип. 1. С. 157-169; Оніщенко О. Жінки в суспільнополітичному житті України. 1917 рік: Автореф. дис... канд. іст. наук. Київ, 2008.
} 
Л. Петришиної20, в яких розкрито політичні, соціально-економічні та духовні аспекти «жіночого питання» в Україні початкового етапу Української революції 19171921 рр. Однак, попри значну кількість наукових публікацій, які прямо чи опосередковано торкаються окресленої у цій науковій розвідці проблеми, в більшості 3 них вона висвітлюється фрагментарно чи неповно.

Отже, враховуючи здобутки науковців у вивченні проблеми політичної емансипації жінок в Україні на початковому етапі Української революції 1917-1921 pp., можна стверджувати, що дотепер все ще залишаються невизначеними деякі аспекти зазначеної наукової проблеми та існує потреба у проведенні їі комплексного дослідження. Проте, спираючись на наукові доробки вітчизняних і зарубіжних істориків українського походження, можна висвітлити основні зміни у суспільнополітичному становищі жінок в Україні протягом березня - листопада 1917 p.

Мета дослідження - відобразити гендерно-політичний аспект розвитку українського суспільства на початковому етапі Української революції 1917-1921 pр. крізь призму проблеми зростання політичної свідомості жіноцтва.

Виклад матеріалу. Лютнева революція в Росії 1917 р. значним чином вплинули на українське суспільство. Так, вона не тільки сприяла зростанню української національної свідомості та відповідно піднесенню українського національновизвольного руху в Наддніпрянщині 21 , але й виступили як каталізатор соціальної емансипації жінки, ставши черговим кроком на шляху до її урівноправнення з чоловіком у суспільно-політичному житті краю22.

Гендерні трансформації в українському суспільстві на початковому етапі Української революції 1917-1921 рр. були пов'язані зі зміною соціально-політичного статусу жінки в Україні, а саме зі зміцненням її соціальної позиції у публічній сфері життя суспільства 23 . Варто наголосити, що дані обставини не виникли внаслідок радикальних суспільних змін, оскільки не суперечили загальноприйнятому соціальному статусу жінки в українському суспільстві 24 , тому й стали логічним продовженням життєдіяльності демократично налаштованого соціуму, що нарешті звільнився від нав'язаного йому Російською імперією та ментально чужого для нього патріархального укладу життя 25 . До того ж вкотре зростанню можливостей жінки в українському суспільстві сприяло й саме жіноцтво, особливо його соціально активна частина, яка доклала чимало зусиль до зростання ролі жінки в соціумі саме своєї участю у розбудові української державності 26.

Загальнодержавні зміни у Російській імперії наприкінці лютого 1917 р. швидко охопили Наддніпрянщину, пробудивши громадську активність її населення. Так, вже на початку березня 1917 р. розпочалась Українська революція 1917-1921 рр.

20 Петришина Л. Гендерні особливості українського національного руху...; Петришина Л. Жіночий рух в Україні у 1917 р. // Наукові записки Вінницького державного педагогічного університету імені М. Коцюбинського. Серія: Історичні науки. 2006. № 1. С. 145-149.

21 Лабур О. Вказ. пр. С. 44.

22 Кобченко К. Гендерні зміни в українському суспільстві в сер. XIX - на поч. XX ст. як складова європейських цивілізаційних процесів // Українознавчий альманах. 2012. № 8. С. 272.

23 Петришина Л. Жіночий рух в Україні у 1917 р.... С. 146.

24 Фатхутдінова I. Роль української жінки в сім'ї та суспільстві // Науковий вісник. Серія «Філософія». Харків: ХНПУ, 2015. Вип. 45 (Частина I). С. 68.

25 Жіночі студії в Україні: Жінка в історії та сьогоденні / За заг. ред. Л.О. Смоляр. Одеса: Астропринт, 1999. 440 с.

26 Кобченко К. Вказ. пр. С. 273. 
навколо якої згрупувалося багато ключових питань пов'язаних із соціальноекономічним і суспільно-політичним оновленням українського суспільства, а також відродженням української державності 27.

Українська революція 1917-1921 рр. надала можливість українському жіноцтву проявити свою політичну активність пов'язану із національним і суспільнополітичним піднесенням краю28. Зокрема, першому та другому етапам доби УЦР (березень - листопад 1917 р.) належить особливе місце в історії українського жіночого руху, адже саме у цей період в українському суспільстві були створені належні умови для самореалізації жінок у державно-політичній сфері 29.

Революційні події 1917 р., що втягнули патріотично налаштоване соціально активне жіноцтво України у водоверть суспільно-політичного життя краю, перш за все, були пов'язані з утворенням і діяльністю УЦР 30.

Виникнувши у березні 1917 р. як інституційна структура громадянського суспільства Наддніпрянщини, УЦР модифікується із громадсько-політичного центру в керівний орган українського національно-визвольного руху, ставши певним державотворчим потенціалом Української революції 1917-1921 рр. ${ }^{31}$

В авангарді УЦР була культурно-мистецька інтелігенція, а саме: члени клубу «Родина»32, очолюваного відомою українською громадською діячкою Наддніпрянщині - Л.Старицькою-Черняхівською, та Товариства українських поступовців (ТУП) 33 . У сучасних наукових публікаціях досить поширеною є думка, що саме цій соціально активній жінці належить ініціатива, яку підтримали представники всіх українських громадсько-політичних організацій, запропонувати М. Грушевському обійняти посаду голови УЦР34. Це говорить, насамперед, про те, що українському національно-демократичному середовищу першої чверті XX ст. був притаманний гендерний паритет, який воно поширило на сферу публічної влади в Україні одразу ж після початку Української революції 1917-1921 pр.

Яскравим свідченням того, що тогочасне українське суспільство стало на шлях гендерної рівності у сфері публічної влади, не чекаючи офіційних змін у гендерній політиці та, відповідно, у законодавстві Російської держави, стала участь більш як двох десятків жінок у розбудові української державності. Так, до депутатського складу УЦР першого скликання, що розпочав свою діяльність у березні 1917 р., потрапило одинадцять жінок 35 , серед яких від: ТУП були Л. Старицька-Черняхівська та Л. Яновська; УЖС - В. Нечаївська; київських культурно-освітніх організацій 3. Мірна, М. Грушевська, В. О’Коннор-Вілінська та С. Русова; Українського педагогі-

\footnotetext{
27 Романцов В. Суспільні процеси в Маріупольському повіті на початку революції (весна 1917 р.) // Схід. 2015. № 3. С. 65.

28 Кочерга О. Вказ. пр.

29 Петришина Л. Гендерні особливості українського національного руху.... С. 18.

30 Смоляр Л. Жіночі долі в контексті історії української державності // Етнічна історія народів Європи. 2000. Вип. 7. С. 11.

31 Петришина Л. Гендерні особливості українського національного руху... С. 19.

32 Верстюк В. Склад і структура Української Центральної Ради // Проблеми вивчення історії Української революції 1917-1921 років. Київ: Інститут історії України НАН України, 2009. Вип. 4. С. 7.

${ }_{33}$ Кирієнко О. Перші хвилини Української революції у спогадах Людмили СтарицькоїЧерняхівської // Український археографічний щорічник. Київ, 2007. Вип. 12. С. 521.

34 Петришина Л. Гендерні особливості українського національного руху... С. 19.

35 Мужук М. Суспільно-правовий статус та громадсько-політична діяльність жінок Чернігівщини...
} 
чного товариства - О. Пащенко ${ }^{36}$.

До своїх обов'язків депутатки ставились досить відповідально й ефективно виконували покладені на них функції та завдання37. Зокрема, одна з представниць соціально активного жіноцтва України першої третини XX ст. із цього приводу зазначала, що жінки-депутати УЦР не маючи такого досвіду політичної діяльності, щоб з легкістю долати труднощі, що виникали внаслідок незвичних для них до березня 1917 р. значно розширених масштабів роботи, все ж знаходили сили самовіддано служили українському народові та продовжували палко сповідувати українську національну ідею 38.

Про активізацію політичної свідомості жіноцтва у перший і другий етапи доби УЦР засвідчує активна громадська позиція та діяльність низки українських жіночих товариств ліберально-демократичного та національно-патріотичного типу, які брали участь у процесі розбудови української державності ${ }^{39}$.

Провідна роль в їхньому згуртуванні в окреслений період належить УЖС ${ }^{40}$. Він виявився одним із перших в Україні національним жіночим громадським об’єднанням, яке згуртувало навколо ідеї рівних із чоловіками прав і можливостей, а також обов'язків у громадській діяльності на благо українського народу представниць ліберально-демократичного та національно-патріотичного типів жіночих організацій 41.

Спочатку, 3 (16) квітня 1917 р. було засновано Тимчасову Раду (ТР) УЖС, очільницею якої стала провідна діячка українського жіночого руху - В. Нечаївська42. Питання стосовно членства у цьому об'єднанні буде вирішене трохи пізніше: під час роботи Першого всеукраїнського жіночого з'їзду, що проходив 14-16(2729) вересня 1917 р. у Києві 43.

Через тиждень ТР УЖС звертається до жіноцтва України із призовом підтримати чоловіків у розбудові української державності. Проте, у відозві «До українських жінок» знайшли місце й питання пов'язані безпосередньо з соціальним становищем жінки в Україні. Так, у документі вказувалось на обмежені, у порівнянні з чоловіками, політичні, економічні та культурні можливості українського жіноцтва в соціумі, а також відсутність у них умінь, на рівні з чоловіками нести обов'язки громадської роботи в українських інтересах 44 . Ця відозва стала ще одним підтвердженням того, що для представниць українського жіночого руху доби УЦР, як і їхнім попередницям, було властиве поєднання гендерного та національного питання.

ТР УЖС закликала соціально активне жіноцтво України об’єднатися під гаслами: «Українська національна ідея», «Рівних права та можливості для жінок і чоловіків», «Рівність у громадських обов'язках жінок і чоловіків», «Матеріальне забезпечення жінок», «Піднесення загальноосвітнього рівня українського жіноцтва» 45 .

\footnotetext{
36 Петришина Л. Жіночий рух в Україні у 1917 р... С. 145-146.

37 Петришина Л. Гендерні особливості українського національного руху... С. 18-19.

38 Петришина Л. Жіночий рух в Україні у 1917 р... С. 145-146.

39 Оніщенко О. Жінки в суспільно-політичному житті України. 1917 рік. С. 14.

40 Смоляр Л. Жіночі долі в контексті історії української державності... С. 12.

41 Оніщенко О. Трансформація гендерних стереотипів... С. 162, 163

42 Петришина Л. Гендерні особливості українського національного руху... С. 19.

43 Смоляр Л. Жіночі долі в контексті історії української державності... С. 12.

44 Петришина Л. Гендерні особливості українського національного руху... С. 19.

45 Петришина Л. Жіночий рух в Україні у 1917 р... С. 146.
} 
Члени цього об'єднання вважали, що обов'язком всіх політично свідомих українок має стати спільна праця разом із чоловіками задля відродження української державності46. Звернення представниць УЖС до громадськості, зокрема під час проведення Українського національного конгресу (УНК) у квітні 1917 р. та вересневого з'їзду культурно-освітніх товариств «Просвіта», засвідчило провідну роль у діяльності українського жіночого руху - української національної ідеї. Наприклад, досить промовистими виступами з цього приводу на вищевказаних зібраннях відзначились такі соціально активні жінки того часу як В. Нечаївська та С. Русова 47.

На УНК, внаслідок переобрання 8 (21) квітня 1917 р. складу УЦР, до депутатства другого скликання (141 член) потрапило 9 жінок48. Це на три депутатки менше, ніж під час першого скликання, але їхня наявність (8\% від загальної кількості депутатів - Aвт.) ще раз доводить, що незважаючи на те, що у Російській державі процес політичної емансипації жінок тільки розпочався ${ }^{49}$, на території України він тривав вже другий місяць.

Про те, що українське суспільство прагне досягнути гендерного паритету у сфері публічної влади, засвідчили виступи присутніх на цьому Конгресі громадських діячок, які не залишили поза своєю увагою дану обставину та вказали на неї делегатам зібрання, наполягаючи на необхідності збільшення жіночого представництва в УЦР50.

Заклики активісток були почуті. Через чотири місяців - 8 (21) серпня 1917 р., мандатною комісією IV Загальних зборів від політичних партій був оприлюднений список нового складу УЦР51. Так, із 656 депутатських місць жінкам віддали 1652 (24\% від загальної кількості депутатів - Aвт.). Зокрема, до УЦР третього скликання потрапили: за територіальним представництвом - М. Грушевська, 3. Мірна, Л.Старицька-Черняхівська, В. О’Коннор-Вілінська та С.Русова; від освітян О. Пащенко; від Всеукраїнської ради робітничих депутатів - Н. Захарченко, О. Клєр, М. Лисиченко та Ю. Шевченко; від української громади м. Саратова - К. Любинська; від національних меншин - А. Гербер, Г.Заславська-Круповецька, Е. Каганова, Л. Рабінович, В. Ревзіна та С. Фукс 53 . Тобто, вже у три рази більше місць було закріплено за жінками-депутатами, що вкотре демонструє наявність в Україні високого для того періоду рівня активізації політичної свідомості жіноцтва та прагнення тогочасного українського суспільства до досягнення гендерного паритету у сфері публічної влади в Україні.

Повертаючись до безпосередньої діяльності УЖС варто зазначити про загальні збори його членів, що відбулися 12 (25) квітня 1917 р. Під час цього зібрання пат-

\footnotetext{
46 Потапюк Л. Діяльність жіночих громад в Україні як джерело забезпечення ґендерного паритету (друга половина XIX - перша третина XX століття) // Наукові записки Тернопільського національного педагогічного університету імені Володимира Гнатюка. Серія: Історія. 2015. № 1. С. 22.

47 Петришина Л. Гендерні особливості українського національного руху... С. 19.

48 Петришина Л. Жіночий рух в Україні у 1917 р... С. 147.

49 Нестерцова-Собакарь О. Вказ. пр. С. 202.

50 Петришина Л. Жіночий рух в Україні у 1917 р... С. 147; Українська Центральна Рада: документи і матеріали: у 2 т. / НАН України, Ін-т історії України, Центр. держ. архів вищ. органів влади і упр. України. Київ: Наук. думка, 1996-1997. Т. 1 : 4 березня - 9 грудня 1917 р. / упоряд.: В.Ф. Верстюк (керівник) [та ін.]; редкол.: В.А. Смолій (відп. ред.) [та ін.]. 1996. С. 327, 335.

${ }^{51}$ Верстюк В.Ф. Склад і структура Української Центральної Ради... С. 10.

52 Петришина Л. Жіночий рух в Україні у 1917 р... С. 147.

53 Українська Центральна Рада: документи і матеріали... С. 327, 335.
} 
ріотично налаштована жіноча громада обрала постійну раду у складі 15 осіб, незмінну представницю від УЖС до УЦР, а також затвердила статут організації54.

3 перших же днів своєї громадсько-політичної діяльності, в контексті українського національно-визвольного руху, УЖС досить динамічно поповнювався новими членами, об’єднавши у своїх лавах сотні учасниць із різних губерній України 55 . Про популярність цього жіночого об’єднання у краї говорить низка його осередків, що були відкриті у шести з дев'яти українських губерній: Волинській, Київській, Полтавській, Чернігівській, Харківській і Херсонській 56.

Вище згадані факти також вказують на зміну соціально-політичного статусу жінки в українському суспільстві, що у черговий раз підкреслює наявність в українському соціумі процесу активізації політичної свідомості жіноцтва зі стимулюванням їхньої громадської активності.

Серйозне ставлення українського суспільства до проблеми політичної емансипації жінок в Україні підтверджує створений влітку 1917 р. у Києві друкований орган УЖС - часопис «Жіночий вісник», який називали «рупором» жіноцтва України ${ }^{57}$. Його головним редактором була Л. Старицька-Черняхівська58. I хоча видання офіційного пресового органу УЖС було нетривалим, лише протягом 1917 р., проте це вже був значний прогрес для тогочасного українського суспільства, оскільки він був першим українським журналом, що побачив світ після вимушеного припинення діяльності редакцій українських часописів на початку Першої світової війни 59 .

Редакція відповідного друкованого періодичного видання багато уваги приділяла політичним подіям в Україні. Наприклад, в одному з його номерів була розміщена програма Комітету УЦР, в якій зазначалося про основні напрямки діяльності УЖС та вказувалось її гасло «Рівність у правах з чоловіками»60. Це, зі свого боку, засвідчувало не лише наміри української національної державно-політичної еліти сприяти політичній емансипації жінок в Україні, але й демонструвало їхні прагнення досягнути подальшого розвитку УЖС, але вже під егідою УЦР.

Стосовно останнього положення, то варто наголосити, що УЖС постійно перебував у тісному контакті з УЦР. Вважалось, що остання була верхом цього жіночого об’єднання61. Зокрема, про це свідчить участь УЖС у діяльності першої державної інституції, створеної членами УЦР та очолюваної безпосередньо ії головою М. Грушевським, - Комітеті допомоги українцям-виселенцям. Як і представники інших громадських організацій і політичних партій, що ввійшли до складу відповідного Комітету, представниці УЖС опікувалися питанням повернення на Батьківщину українців, виселених ще за царського режиму з території Наддніпрянської

\footnotetext{
54 Багатопартійна українська держава на поч. XX ст.: програмні документи перших українських політичних партій / упор. В. Журавський. Київ: Пошук, 1992. С. 72; Кудлай О. Протоколи засідань Комітету Української Центральної Ради (квітень 1917 р.) // Проблеми вивчення історії Української революції 1917-1921 рр. 2013. Вип. 9. С. 367.

55 Оніщенко О. Жінки в Українській Центральній Раді... С. 87.

56 Петришина Л. Гендерні особливості українського національного руху... С. 19.

57 Філіпенко Л. Російські жіночі журнали початку XX століття: розмаїття типів та напрямів // Актуальні проблеми вітчизняної та всесвітньої історії: збірник наукових праць. 2011. Вип. 14. С. 315. 58 Міщенко Д. Вказ. пр. С. 114.

59 Філіпенко Л. Вказ .пр. С. 316; Мудра І., Куца М. Вказ. пр. С. 46.

60 Міщенко Д. Вказ. пр. С. 114.

61 Оніщенко О. Жінки в Українській Центральній Раді... С. 87.
} 
України 62.

«Жіночий вісник» не оминав своєю увагою становища жінок за кордоном, наприклад, у США. Втім більшість його публікацій були присвячені саме з'ясуванню соціальної ролі жінки в українському суспільстві63. До того ж це видання, поєднуючи на своїх сторінках жіноче та національне питання, засвідчило високий рівень освіченості та політичної свідомості авторів його творчих доробків64.

Використовуючи друковані засоби масової інформації та залучаючи до своїх лав освічених і талановитих громадсько-політичних діячок, патріотично налаштоване соціально активне жіноцтво, зокрема представниці українського жіночого руху, першого та другого етапів доби УЦР зуміло створити розлогу популярну літературу, в якій приділялась увага важливим і цікавим для тогочасного українського суспільства жіночим питанням ${ }^{65}$.

Визначною віхою гендерно-політичного розвитку українського суспільства на початковому етапі Української революції 1917-1921 рр. вважається організація та проведення Першого всеукраїнського жіночого з'їзду, що відбувся, як вже вище зазначалось у кінці вересня 1917 р. у Києві, у стінах легендарного клубу «Родина» 66 .

У роботі з'їзду взяли участь представниці всіх українських жіночих організацій. На цьому зібранні лунали заклики про соборність етнічних українських земель; еволюцію державно-правового статусу України у напрямку встановлення у ній республіканської форми державного правління; про те, що подальшу долю її населення мають вирішувати Українські Установчі збори; про передачу підприємств краю трударям; про соціальний захист дітей і жінок тощо67.

Ще одним промовистим свідченням активізації політичної свідомості жінок в Україні стало рішуче висловлювання патріотично налаштованого соціально активного жіноцтва України про необхідність побудови української державності. Доказом того, що делегатки українських жіночих об’єднань виявляли готовність сприяти та підтримувати державотворчу діяльність УЦР, є прийнята на цьому зібранні резолюція «Про політичні справи». У цій постанові, зокрема, визначалась оптимальна для українського народу форма державного правління - республіка, що побудована на демократичних засадах, та вказувалось на Установчі збори як на кращий спосіб волевиявлення народу68.

Однак на цьому прояви фактичного перетворення жінок в Україні з об'єкта у суб’єкт політичної діяльності не закінчились. Це підтверджували й виступи делегаток з'їзду, які відкрито висловлювали свій соціальний протест проти національної політики Тимчасового уряду та тих представників російської громадськості, котрі чинили не демократично, осуджуючи прагнення народів колишньої Російської імперії на самовизначення 69.

\footnotetext{
62 Олійник Н. Громадсько-політична активність українських жінок (1917-1939рр.)... С. 178.

63 Міщенко Д. Вказ. пр. С. 114.

${ }^{64}$ Сташина I. Феміністичний рух країн Заходу та жіночий рух в Україні: екскурс в минуле // Мова і культура. Київ: Вид. Дім Д. Бураго, 2008. Вип. 10. Т. VI (106). С. 170.

65 Морщакова О. Вказ. пр.

66 Яценко Л. Жіночий рух України: етапи становлення // Наукові записки з української історії: Збір. наук. праць. Переяслав-Хмельницький. 2008. Вип. 21. С. 387.

67 Петришина Л. Гендерні особливості українського національного руху... С. 19.

68 Ibidem.

${ }^{69}$ Сташина I. Вказ. пр. С. 170.
} 
Ще одним, не меншої ваги документом прийнятим на Першому всеукраїнському жіночому з'їзді стала резолюція «Народна освіта». В ній доводилася необхідність вивчення українським народом своєї рідної мови та зазначалася важливість цієї національної освітньої справи для розбудови української державності ${ }^{70}$.

Про політичну емансипацію жінок в Україні на початковому етапі Української революції 1917-1921 рр. свідчить і ухвала на відповідному жіночому зібранні звернення-привітання до 3'їзду народів Росії, що тими днями проходив у Києві з приводу принципових питань, які стосувались національно-державного будівництва народів, що населяли територію колишньої Російської імперії71. Це звернення було виголошено з трибуни на одному із засідань 3'їзду народів Росії72.

Як бачимо, сама ідея організації та проведення Першого Всеукраїнського жіночого з'їзду є явним прикладом гендерно-політичного аспекту розвитку українського суспільства, направленого на вдосконалення інституту політичної емансипації жінок в Україні шляхом активізації їхньої політичної свідомості та долучення останніх до впровадження української національної ідеї в життя. Так, представниці ліберально-демократичних і націонал-патріотичних українських жіночих організацій першого та другого етапів доби УЦР разом із чоловіками, представниками українського національно-визвольного руху, прагнули втілити у життя ідею консолідації всіх українських національних сил для здійснення найвищого ідеалу побудувати суверенну та соборну українську державу73.

Висновки. Отже, проведене дослідження відносно проблеми виходу українського суспільства на початковому етапі Української революції 1917-1921 рр. на якісно новий рівень у питанні політичної емансипації жінок дає підстави стверджувати, що:

- $\quad$ даному процесу сприяли декілька об’єктивних обставин: по-перше, з поваленням самодержавства у Росії розпочалася пришвидшена, спрямована на злам патріархальних підвалин суспільства модернізація; по-друге, позитивне сприйняття українським суспільством тогочасних загальноєвропейських тенденцій щодо жіночої емансипації; по-третє, традиційний демократизм українського соціуму;

- його особливістю стало те, що в українському суспільстві розпочався процес активізації політичної свідомості жінок ще до того, як Тимчасовий уряд офіційно змінив публічно-правовий статус жінки у Російській державі;

- проявився він безпосередньо у долученні соціально активного жіноцтва України з перших днів Української революції 1917-1921 рр. до всіх сфер публічного життя українського суспільства, в тому числі вони отримали можливість обіймати високі державні посади у структурах вищих органів влади та управління УЦР;

- результатом перетворення жінок України з об’єкта у суб'єкт політичної діяльності став їх вагомий внесок в українське національне відродження періоду Української революції 1917-1921 рр., насамперед, у розбудову української держав-

\footnotetext{
70 Петришина Л. Жіночий рух в Україні у 1917 р... С. 147.

71 Яценко Л. Вказ. пр. С. 388.

71 Ялдовська О. Проблема етнічних меншин України в матеріалах 3'їзду народів Росії // Наукові праці Миколаївського державного гуманітарного університету ім. П. Могили комплексу «КиєвоМогилянська академія». Серія: Історичні науки. 2008. Т. 83. Вип. 70. С. 34.

72 Петришина Л. Гендерні особливості українського національного руху... С. 19.

73 Рихтицька Д. Українська жінка в дзеркалі життя і боротьби // Визвольний шлях. 1996. № 5. C. 523.
} 
ності та досвід державно-політичного управління, якого до березня 1917 р. вони не мали.

Перспективи подальшого дослідження. Ґрунтовний аналіз та узагальнення поглядів на проблему щодо політичної емансипації жінок в Україні на початковому етапі Української революції (березень - листопад 1917 р.) дав змогу окреслити перспективи подальших наукових розвідок у даному напрямі, перш за все, доцільність комплексного дослідження, переосмислення та нової оцінки низки питань пов'язаних із гендерно-політичним аспектом розвитку українського суспільства у цей і наступні етапи Української революції 1917-1921 рр.

\section{REFERENCES}

Bohachevska-Khomiak, M. (1995). Bilym po bilomu: Zhinky v hromadskomu zhytti Ukrainy, 1884-1939 [White on White: Women in Public Life in Ukraine, 1884-1939]. Kyiv [in Ukrainian].

Fatkhutdinova, I. (2015). Rol ukrainskoi zhinky v sim'i ta suspilstvi [The role of Ukrainian women in the family and society]. Naukovyi visnyk. Seriia «Filosofiia», 45 (Vol. I), 62-84 [in Ukrainian].

Filipenko, L. (2011). Rosiiski zhinochi zhurnaly pochatku XX stolittia: rozmaittia typiv ta napriamiv [Russian women's magazines of the early twentieth century: a variety of types and trends]. Aktualni problemy vitchyznianoi ta vsesvitnoi istorii: zbirnyk naukovykh prats, 14, 307-316 [in Ukrainian].

Kyriienko, A. (2007). Pershi khvylyny Ukrainskoi revoliutsii u spohadakh Liudmyly StarytskoiCherniakhivskoi [The first minutes of the Ukrainian revolution in the memoirs of Liuudmyla Starytska-Cherniakhivska]. Ukrainskyi arkheohrafichnyi shchorichnyk, 12, 517-533 [in Ukrainian].

Kobchenko, K. (2012). Genderni zminy v ukrainskomu suspilstvi v seredyni XIX - na poch. XX st. yak skladova yevropeiskykh tsyvilizatsiinykh protsesiv [Gender changes in the Ukrainian society in the middle XIX - early XX century as a component of European civilizational processes]. Ukrainoznavchyi almanakh, 8, 271-274 [in Ukrainian].

Kocherha, 0. (2012). Sofiia Rusova pro rol zhinky u suspilnomu rozvytku [Sofia Rusova on the role of women in social development]. Retrieved from: https://eprints.oa.edu.ua/5362/1/6.pdf_[in Ukrainian].

Kudlai, O. (2013). Protokoly zasidan Komitetu Ukrainskoi Tsentralnoi Rady (kviten 1917 r.) [Protocols of the meetings of the Ukrainian Central Rada Committee (April 1917)]. Problemy vyvchennia istorii Ukrainskoi revoliutsii 1917-1921 rr., 9, 320-383 [in Ukrainian].

Labur, 0. (2019). «Vikno mozhlyvostei?»: henderna sytuatsiia na khvyli revoliutsiinoi polityky z liutoho 1917 r. v Ukraini [«Window of Opportunities?»: Gender Situation on the Wave of Revolutionary Politics from February 1917 in Ukraine]. Storinky istorii: zbirnyk naukovykh prats, 49, 42-58 [in Ukrainian].

Mishchenko, D. (2011). Polityzatsiia ukrainskoho zhinochoho rukhu naprykintsi XIX - na pochatku XX st. [Politicization of the Ukrainian women's movement in the late 19th - early 20th centuries]. In Zbirnyk naukovykh prats studentiv, aspirantiv i molodykh vchenykh «Moloda nauka - 2011» (Vol. 5, pp. 113-115). Zaporizhzhia: Prosvita [in Ukrainian].

Morshchakova, 0. (2012). Istoryko-sotsialni ta pravovi aspekty hendernoi rivnosti [Historical, social and legal aspects of gender equality]. Retrieved from: http://divovo.in.ua/download/morshakova-os-istoriko-socialeni-ta-pravovi-aspekti-gendernoy.doc [in Ukrainian].

Mudra, I., Kutsa, M. (2018). Evoliutsiia ukrainskykh zhinochykh zhurnaliv [Evolution of Ukrainian women's magazines]. Sotsialni komunikatsii, 6 (58), $45-49$ [in Ukrainian].

Muzhuk, M. (2014). Suspilno-pravovyi status ta hromadsko-politychna diialnist zhinok Chernihivshchyny u period natsionalno-kulturnoho vidrodzhennia XIX - pochatku XX st. [Social and legal status and social and political activities of women of Chernihiv region during the national and cultural revival of the $19^{\text {th }}$ - early $20^{\text {th }}$ centuries]. Retrieved from: http://eprints.kname.edu.ua/44337/_[in Ukrainian].

Oliinyk, N. (2013). Osoblyvosti zaluchenosti zhinok u hromadsko-politychni protsesy (seredyna XIX st. pochatok XX st.) [Peculiarities of women's involvement in social and political processes (midnineteenth century - early twentieth century)]. Gileya: Hileia: naukovyi visnyk, 72, 75-80 [in Ukrainian].

Oliinyk, N. (2013). Hromadsko-politychna aktyvnist ukrainskykh zhinok (1917-1939 rr.) [Social and political activity of Ukrainian women (1917-1939)]. Kyiv [in Ukrainian].

Nestertsova-Sobakar, 0. (2016). Pravove stanovyshche zhinky na ukrainskykh zemliakh u skladi Rosiiskoi imperii u druhii polovyni XIX - na pochatku XX st: monohrafiia [The legal status of women in the 
Ukrainian lands within the Russian Empire in the second half of the XIX - early XX century: monograph]. Dnipro: DGUVD [in Ukrainian].

Onishchenko, 0. (2008). Zhinky v suspilno-politychnomu zhytti Ukrainy. 1917 rik [Women in the social and political life of Ukraine. 1917]. (Extended abstract of Candidate's thesis). Kyiv [in Ukrainian].

Onishchenko, 0. (2016). Zhinky v Ukrainskii Tsentralnii Radi [Women in the Ukrainian Central Rada]. Literatura ta kultura Polissia. Seriia: Istorychni nauky, 85, 81-90 [in Ukrainian].

Onishchenko, 0. (2015). Transformatsiia hendernykh stereotypiv u konteksti revoliutsiinykh podii 1917 roku [Transformation of gender stereotypes in the context of the revolutionary events of 1917]. Naukovi zapysky Natsionalnoho universytetu «Ostrozka akademiia». Seriia: Henderni doslidzhennia, 1, 157-169 [in Ukrainian].

Petryshyna, L. (2016). Henderni osoblyvosti ukrainskoho natsionalnoho rukhu XIX - pochatku XX st. [Gender characteristics of the Ukrainian national movement in the $19^{\text {th }}-$ early $20^{\text {th }}$ century]. Naukovyi visnyk mizhnarodnoho humanitarnoho universytetu, 2-2211, 14-19 [in Ukrainian].

Petryshyna, L. (2006). Zhinochyi rukh v Ukraini u 1917 r. [Women's movement in Ukraine in 1917]. Naukovi zapysky Vinnytskoho derzhavnoho pedahohichnoho universytetu imeni M. Kotsiubynskoho. Seriia: Istorychni nauky, 1, 145-149 [in Ukrainian].

Potapiuk, L. (2015). Diialnist zhinochykh hromad v Ukraini yak dzherelo zabezpechennia gendernoho parytetu (druha polovyna XIX - persha tretyna XX stolittia) [The activity of women's communities in Ukraine as a source of ensuring gender parity (second half of the $19^{\text {th }}$ - first third of the $20^{\text {th }}$ century)]. Naukovi zapysky Ternopilskoho natsionalnoho pedahohichnoho universytetu imeni Volodymyra Hnatiuka. Seriia: Istoriia, 1, 18-23 [in Ukrainian].

Rychtytska, D. (1996). Ukrainska zhinka v dzerkali zhyttia i borotby [Ukrainian woman in the mirror of life and struggle]. Vyzvolnyi shliakh, 5, 518-528 [in Ukrainian].

Romantsov, V. (2015). Suspilni protsesy v Mariupolskomu poviti na pochatku revoliutsii (vesna 1917 r.) [Public processes in the Mariupol district at the beginning of the revolution (spring 1917)]. Skhid, 3, 64-67 [in Ukrainian].

Smolii, V. (Ed.). (1996). Ukrainska Tsentralna Rada: dokumenty i materialy [Ukrainian Central Rada: documents and materials]. Vol. 1: March 4 - December 9, 1917. Kyiv: Naukova Dumka [in Ukrainian].

Smoliar, L. (2000). Zhinochi doli v konteksti istorii ukrainskoi derzhavnosti [Women's destinies in the context of the history of Ukrainian statehood]. Etnichna istoriia narodiv Yevropy, 7, 10-15 [in Ukrainian].

Smoliar, L. (Ed.). (1999). Zhinochi studii v Ukraini: Zhinka $v$ istorii ta sohodenni [Women's Studios in Ukraine: Woman in History and Present]. Odessa: Astroprint [in Ukrainian].

Stashyna, I. (2008). Feministychnyi rukh krain Zakhodu ta zhinochyi rukh v Ukraini: ekskurs v mynule [The Feminist Movement of Western Countries and the Women's Movement in Ukraine: An Excursion into the Past]. Mova i kultura, 10, 166-173 [in Ukrainian].

Tymchenko, Zh. (1982). Uchast zhinok-robitnyts Kyieva u revoliutsiinii borotbi (berezen 1917 - sichen 1918 r.) [Participation of women workers in Kiev in the revolutionary struggle (March 1917 January 1918)]. Ukrainian historical journal, 1, 57-65 [in Ukrainian].

Verstiuk, V. (2009). Sklad i struktura Ukrainskoi Tsentralnoi Rady [Composition and structure of the Ukrainian Central Rada]. Problemy vyvchennia istorii Ukrainskoi revoliutsii 1917-1921 rokiv, 4, 5-30 [in Ukrainian].

Yadlovska, A. (2008). Problema etnichnykh menshyn Ukrainy v materialakh Z'izdu narodiv Rosii [The problem of ethnic minorities in Ukraine in the materials of the Congress of the peoples of Russia]. Naukovi pratsi Mykolaivskoho derzhavnoho humanitarnoho universytetu imeni P. Mohyly kompleksu «Kyievo-Mohylianska akademiia». Seriia: Istorychni nauky, Vol. 83 (70), 33-39 [in Ukrainian].

Yatsenko, L. (2008). Zhinochyi rukh Ukrainy: etapy stanovlennia [Women's movement in Ukraine: stages of formation]. Naukovi zapysky z ukrainskoi istorii: Zbirnyk naukovykh prats, 21, 386-390 [in Ukrainian].

Zhuravskyi, V. (1992). Bahatopartiina ukrainska derzhava na pochatku XX st.: prohramni dokumenty pershykh ukrainskykh politychnykh partii [Multi-party Ukrainian State in early of the $20^{\text {th }}$ century: program documents of the first Ukrainian political parties]. Kyiv [in Ukrainian]. 


\section{Valeria Motuz}

(Bohdan Khmelnytsky National University of Cherkasy, Cherkasy, Ukraine)

e-mail: v.k.motuz@ukr.net

ORCID: https://orcid.org/0000-0002-9974-7205

\section{Ukrainian Society at Initial Stage of Ukrainian Revolution (March - November 1917): to the Issue of Political Emancipation of Women in Ukraine}

The paper is devoted to the problem of activating the political consciousness of women in Ukraine. The study and promotion of this issue can have a positive impact on the development of the Ukrainian women's movement and the achievement of de facto gender parity in the field of public authority in Ukraine.

1917 should be considered as one of the important periods in the women's history of Ukraine since at that time a new vector of its development came into force: active politicization of women's consciousness with their civic activity stimulating by appointing women to executive positions in national bodies of state power in the first and second stages of the Central Rada of Ukraine period.

Unlike Russian society, Ukrainian society did not expect an official change in the gender policy of the Provisional Government, but immediately showed its readiness for national democratic transformations to achieve gender parity, in particular, started to involve socially active women in building up of Ukrainian statehood since the beginning of the Ukrainian Revolution of 1917-1921.

Socially active women were the representatives of the Ukrainian national liberation movement. The revival of Ukrainian statehood, democracy, and gender parity in the society were considered being its most important ideological principles.

In 1917-1921, Ukrainian society reached a qualitatively new level in the politicization of women's consciousness. It was evidenced by the creation and effective activity of a unifying, for all women's organizations of Ukraine, center - the Union of Ukrainian Women, socially useful work in the bodies of state power, deputizing in the Central Rada of Ukraine, and membership in the Little Rada.

The actual transformation of a woman from an object into a subject of political activity was accompanied not only by positive reactions of Ukrainian society to the process but also by critical interpretation of their activities by members of the Ukrainian national liberation movement of the Central Rada of Ukraine.

Keywords: Ukrainian women, women's movement, political emancipation of women, political consciousness of women 